\title{
Breaking Bad News: Penal Populism, Tabloid Adversarialism and Brexit
}

Chris Greer and Eugene McLaughlin

The Political Quarterly, online first, 30 ${ }^{\text {th }}$ March 2018 (doi:10.1111/1467-923X.12506)

\begin{abstract}
This article analyses the role that British conservative tabloid newspapers play in promoting penal populism and delegitimising liberal prison reform initiatives. Principally, we consider how different sections of the British press reacted to the then Prime Minister David Cameron's prison reform speech of 8 February 2016. The analysis illustrates how different newspapers cohered around two diametrically opposing interpretations of the scandalous state of the prison system, reflecting distinctive penal philosophies and moral positions. In the context of penal populism and the populist furies unleashed by the Brexit campaign, the central research finding is that the comparatively passive and equivocal support offered by the broadsheets was no match for the vitriolic attack mounted by the conservative tabloids on the 'soft justice' parts of Cameron's prison reform agenda. We conclude by arguing that the stark lesson to be learned is that the scandal-ridden prison is a particularly toxic issue marked by serial policy failure. Consequently, in a febrile, intermediatised penal populist context, why would any political leader take on the manifest risks associated with embarking on liberal prison reform?
\end{abstract}

Keywords: Brexit, penal populism, prison reform, punitiveness, scandal, tabloid adversarialism

\section{Introduction}

This article investigates the role that British conservative tabloid newspapers play in promoting penal populism and delegitimising liberal prison reform initiatives. Because of the tighter legal restrictions around objectivity and impartiality that apply to the Britain's broadcast news media, newspapers remain pivotal in setting the public and policy agendas around criminal justice matters. The article is built around an analysis of how different sections of the British press reacted to the then Prime Minister David Cameron's speech on 8 February 2016, in which he called for prison reform to be one of the great progressive causes of British politics. Trailed as the first significant prison speech by a Prime Minister in twenty years, we argue that Cameron enjoyed a brief moment of press consensus around his core claim that the scandalous state of the prison system justified sweeping reforms. That, however, is where the press consensus ended.

Our analysis of national newspaper coverage for 2016 illustrates how different sections of the British press cohered around two diametrically opposing interpretations of the scandalous prison, reflecting distinctive penal philosophies and moral positions. In line with 
Cameron's speech, liberal and conservative broadsheets agreed that the scandal was the over-crowded and dysfunctional nature of an under-funded prison estate. For the conservative tabloids, the scandal was an insufficiently punitive, anarchic prison regime. In the context of penal populism and the populist furies unleashed by the Brexit campaign, the central research finding is that the comparatively passive and equivocal support offered by the broadsheets was no match for the vitriolic attack mounted by the conservative tabloids on the 'soft justice' parts of Cameron's prison reform agenda.

Conservative tabloid adversarialism peaked when the attack on prison reforms was combined with their referendum campaign against the 'evils' of Britain's membership of the European Union. Weaving Brexit into their 'soft justice' British prison scandal enabled the tabloids to attack liberal prison reform on two fronts. Conservative tabloid outrage conjoined unrepentant lags with Islamist terrorists, criminal migrants and foreign criminals. By portraying these 'unpunishable' criminals as making a mockery of British justice, the conservative tabloids were able to reclaim the news agenda and undermine the precarious consensus on prison reform. We conclude by arguing that these polarised interpretations of the state of British prisons, underpinned by contradictory moral positions and penal philosophies, remain a major block against liberal penal reform in England and Wales.

\section{Penal populism}

Criminologists have sought to understand the reasons behind the rise of punitive public sentiments. One of the key aggravating factors they have identified is the dominance of fear and anger about crime in public discourse, and the extent to which its increasing everyday salience can reshape electoral politics and reorient criminal justice policy towards punitive solutions. Perhaps because earlier analyses focused on the broad socio-economic and cultural transformations that were driving prison expansion, the news media were situated within that wider context. There was little explicit, still less in-depth, examination of the news media's role in supporting or challenging penal populism.

In the late 1970s, criminologists suggested that, although Britain's prison system had been in perpetual crisis since the nineteenth century, the crisis was likely to intensify as a result of the shift to an increasingly punitive society. When, as predicted, the crisis intensified, explanations identified the collapse of the guiding philosophy of penal-welfarism as the core of the problem. The turn towards penal pragmatism, lack of adequate funding, and the preoccupation with the risks posed by dangerous offenders were also identified as key causal factors. Penal problems were exacerbated by public fear and anger about rising crimes rates and the breakdown of the political consensus on law and order. By the mid1990s, with prison expansion and the intensification of punitive sentiments, penal populism was identified as posing a fundamental challenge to the promotion of liberal prison reforms.1

Criminological research has recognised the mass media's role in shaping public knowledge about crime and criminal justice, and in driving punitive penal policies through the politicisation of law and order. For some, mass media have heightened crime consciousness 
and increased public fear, anger and resentment by exaggerating the risks of victimisation and the ineffectiveness of the criminal justice system. Others have castigated what is perceived as the power of tabloid law and order campaigns to influence politicians. A consistent 'bad news' message emerges from this body of work. Tabloid newspapers, in particular, stand accused of fomenting and intensifying populist punitive sentiments by: exaggerating the threat posed by a minority of violent predatory offenders; sensationalising exceptional or aberrant crimes; spotlighting inconsistent-and unrepresentativesentencing practices; triggering moral panics about 'new' crimes requiring 'new' forms of punishment; employing simplistic frames of 'good' and 'evil'; highlighting injustices perpetrated against victims by what is conceptualised as an ineffectual criminal justice system; savaging politicians, criminal justice personnel, and experts deemed to be 'soft on crime'; questioning the validity of official crime statistics; and lending editorial support for punitive law and order policies, including the return of capital punishment. 2

Nevertheless, penal reformers continue to believe that there is scope to neutralise rather than acquiesce to tabloid penal populism because 'the public voice' is more nuanced and contradictory than is assumed and the news media are not a monolithic entity. A strategic priority should be to establish a resilient coalition of progressive penologists, penal reformers, policy makers and opinion leaders that is insulated from the periodic public anger generated by tabloid law and order campaigns and short-termist electoral opportunism. The role of the coalition would be to make sure that research findings are central in decision making and demonstrate the damaging social and economic costs of incarceration-centred penal policies. The Howard League for Penal Reform recently published a communication strategy that it proposes can be used to transform the terms of the public conversation and counteract penal populism. 3 The suggestions include: thinking creatively about how to produce and communicate a compelling penal reform narrative; highlighting successful liberal penal policies; contesting news media errors, omissions and distortions; repackaging factual information; working with broadcasters to create reformist storylines that will reach new audiences; and using social media platforms to mobilise online support for liberal penal policies.

It is of course important to keep thinking about new ways to counter the ill-informed, misleading and/or inflammatory styles of penal affairs reporting that is evident across much of Britain's news media. However, it is also important to acknowledge the limits of what can be achieved by penal reformers who are seeking, in effect, to establish an elite consensus regarding what can and cannot be publicly debated. We suggest that the belief that penal populism can be neutralised and prison reforms advanced by a liberal elite using social media platforms, demonstrates a lack of understanding of how tabloid adversarialism is evolving in a radically transformed intermediatised environment. 4 The power of tabloid adversarialism resides in its reflexive ability to generate a striking array of populist positions across a range of social issues. In so doing, these newspapers are able to find interacting breaking points that can tip the balance of public sentiment or political resolve one way rather than the other. 


\section{Press adversarialism}

British national newspapers have always been adversarial. Speaking truth to power, exposing corruption and holding the powerful to account are core to the press' traditional Fourth Estate understanding of itself. In recent decades, however, this adversarialism has become aggressively anti-establishment due to: perceptions of an out-of-touch political class; the need to establish distinction in a ruthlessly competitive $24 / 7$ intermediatised news marketplace; the requirement to impose interpretive order in a chaotic information environment; and mirroring the inversion of the hierarchy of social deference. 5 The moral force and focus of press adversarialism derives from different ideological convictions and is articulated in different ways across tabloid and broadsheet, liberal and conservative newspapers. The Guardian, for example, wears its cosmopolitan moral values on its sleeve. The moral position of the Daily Mail, in contrast, derives from its stated commitment to defend the traditional conservative values of middle England.

The tabloidisation of the British press transformed journalistic practice and the nature of news itself by blurring the boundaries between news and entertainment. It also revamped newspapers' sense of their own power to influence. 6 New printing technologies enabled the production of full-colour images, which formed the centrepieces for increasingly graphic and emotionally charged stories. Tabloid power to invoke consumer empathy, shock and anger was reinforced by melodramatic headlines, moralistic interpretive frameworks, streamlined explanations, and a growing antagonism towards official explanations and perceived failures of institutional authority.

These technological and cultural changes emboldened UK newspapers in claiming to represent the 'public interest', and extended their traditional agenda setting role to one of overt advocacy and activism. The advent of smartphones and social media has rewired the nature and content of news. The public is now woven into the news production process, submitting their views or, more importantly, sending or uploading images. In this digitally networked news environment, consumers are 'producers', 'readers', 'watchers' and 'doers', and everyone is a 'netizen reporter'. The immersive, instantly responsive experience of news both encourages and facilitates the co-production of tabloid adversarialism, and the dynamic is intensifying. Tabloid reporting is at its most morally outraged when stories are built around allegations of systemic institutional failures that threaten 'ordinary decent people'. Britain's failing criminal justice system continues to provide an endless supply of news stories that can catalyse public outrage.7 Sitting at the heart of this failing system is the scandal-ridden prison system.

\section{The scandal-ridden prison: crisis after crisis}

Research across several decades has evidenced the power of tabloid newspapers to shape the penal agenda.8 Although prisons now have a central place in popular culture, they are not by any stretch of the imagination a routine news priority. However, an unremitting resolve to expose the latest 'soft justice' prison scandal has enabled tabloids to construct themselves as watchdogs representing the interests of the law-abiding majority and the 
forgotten victims of crime. Campaigning for retributive sentencing policies and tough prison regimes is justified by the alleged risks posed by dangerous violent offenders. The human rights and privileges allegedly afforded to prisoners are contrasted with those allegedly denied to law-abiding citizens and crime victims. Prisons are routinely presented as holiday camps, or as lifestyle choices for incorrigible, pampered 'lags' living it up behind bars. Stories of rioting prisoners, prison escapes, Parole Board controversies, and the antics of notorious inmates, fuel periodic fits of tabloid outrage. This well-honed 'soft justice' script serves vital ideological functions. It legitimises and normalises the prison as the solution to crime; constructs prisoners as unworthy of sympathy; trivialises or renders invisible the injustices and harms prisoners suffer from imprisonment; exaggerates the failures of noncustodial alternatives; and ridicules attempts by what are perceived to be ideologically motivated wreckers masquerading as 'reformers' seeking to undermine a punishment based criminal justice system.

An insight into the difficulties of trying to work against the adversarial logics of tabloid penal populism is provided by the reaction to and fall-out from the prison reform speech given by David Cameron on 8 February 2016 to Policy Exchange, a conservative think tank.

\section{Great expectations: resetting the prison reform agenda}

Just before attending a crucial summit on European Union reform on 18-19 February 2016, David Cameron, the then Prime Minister, announced that a new era of radical prison reform beckoned.9 The case for reform had been gathering momentum since Cameron had been returned to Downing Street with an outright majority in May 2015. In July 2015, Nick Hardwick, the outgoing chief inspector of prisons had declared that there had been a shocking deterioration in the state of the prisons in England and Wales. This was on the back of a stream of news stories about prison overcrowding, staff shortages, staff corruption, squalid conditions, inmate violence, sexual assaults, suicides, high reoffending rates and an astounding volume of drugs, psychoactive substances, alcohol and mobile phones being confiscated from inmates. The sense of crisis was illustrated by a BBC Panorama undercover investigation in January 2016 which filmed G4S staff at a secure training centre, mistreating young offenders.

David Cameron and Michael Gove, the Minister for Justice, had placed the overhaul of the prison system at the centre of their 'compassionate conservativism' party conference speeches in October 2015. Cameron had accepted that prisons were failing either to protect the public or reform offenders, whilst in an evangelical speech, Gove had called on the Conservative party to support an 'unremitting emphasis' on 'reform, rehabilitation and redemption'.10 In November 2015 it was announced that $£ 1.3$ billion would be spent on building nine new prisons. The construction programme would be part-funded through selling off Victorian prisons. Michael Gove spelt out the rationale:

"This investment will mean we can replace ageing and ineffective Victorian prisons with new facilities fit for the modern world. We will be able to design out the dark corners which too often facilitate violence and drug-taking. And we will be able to 
build a prison estate which allows prisoners to be rehabilitated, so they turn away from crime. It is only through better rehabilitation that we will reduce reoffending, cut crime and make our streets safer." 11

Gove had also set up a review under Dame Sally Coates to make recommendations as to how educational provision in prisons could be reorganised to support offender rehabilitation.

In a carefully choreographed attempt to seize the news agenda, Cameron met inmates at a Warwickshire prison before giving his speech. Building on the cultural revolution policy position Michael Gove had taken as Minister for Education, the prison reform agenda was structured around the need for a fundamental shift in thinking to view prisoners not as 'liabilities to be managed' but as 'potential assets to be harnessed'. Cameron accepted that:

" the failure of our system today is scandalous. 46 per cent of all prisoners will reoffend within a year of release. 60 per cent of short-sentenced prisoners will reoffend within the same period. And current levels of prison violence, drug-taking and self-harm should shame us all. In a typical week, there will be almost 600 incidents of self-harm; at least one suicide; and 350 assaults, including ninety on staff. "

He dismissed the tabloid image of prisons as holiday camps: 'They are often miserable, painful environments. Isolation. Mental anguish. Idleness. Bullying. Self-harm. Violence. Suicide. These aren't happy places. It's lazy to subscribe to the idea that prisoners are somehow having the time of their lives. These establishments are full of damaged individuals'. To cut reoffending rates a sweeping programme of reform would include:

- the creation of a new generation of 'reform prisons';

- the re-empowerment of prison governors who would have control over operational matters and budgets;

- increased transparency and accountability through publishing prison performance league tables comparing reoffending rates, educational attainment and post-prison employment;

- secure academies to replace young offender institutions; experimenting with GPS tagging to facilitate weekend or evening imprisonment for lower risk offenders in employment;

- enabling former prisoners to apply for jobs without declaring their criminal record;

- recruiting a new generation of graduate prison officers;

- paying bonuses to prison staff in high-performing prisons;

- rethinking the treatment of imprisoned pregnant women and mothers with babies;

- jamming phone signals to prisons to deactivate contraband mobile phones;

- tackling violent extremism and radicalisation in prison;

- and streamlining the deportation of foreign prisoners. 


\section{The newspaper reaction}

The most striking thing about the immediate press response was the consensus regarding the need for root-and-branch reform of a scandalous institution. Cameron's call for an urgent rethink on the 'absolutely terrible' fate of 100 infants who were imprisoned because their mothers were serving jail terms was difficult even for the most cynical journalist to contest. But that is where the press consensus ended.

\section{The broadsheet reaction: a question of resources}

All of the broadsheets recognised that Cameron's speech had the potential to be a historic turning point, departing from the 'prison works' refrain articulated by Michael Howard, the then Conservative Home Secretary, in 1993 and subsequently subscribed to by governments of all political persuasions. It was agreed that political leadership on the prison crisis was long overdue in order to put an end to highly damaging swings in policy and practice. The facts spoke for themselves - tax payers were paying an estimated $f 13$ billion a year for a prison regime that saw 46 per cent of prisoners reoffend within twelve months of release. The Guardian and Independent delivered in-depth news coverage alongside commentary backing Cameron. He was lauded for setting aside political partisanship on prison reform and seeking to forge a dialogue with penal reformers. The Minister for Justice, Michael Gove, was praised for reversing the counter-productive punitive measures that his toughtalking predecessor, Chris Grayling, had introduced. Much of Gove's agenda echoed that of Kenneth Clarke when he was Justice Secretary. Both newspapers also exuded a guarded optimism about the hugely challenging process of implementing prison reform, noting that Cameron had made similar policy intonations in the past with little effect. The Prime Minister was reminded that he had contributed to the prison crisis when, in the face of tabloid attacks, the sentencing reforms that lay at the heart of Kenneth Clarke's proposed 'rehabilitation revolution' were abandoned.

A core criticism was that the proposed reforms underestimated the multifaceted nature of the prison crisis. Organisational capacity had been damaged by recurring policy failures and spectacular political U-turns. The reforms would not work without addressing the elephant in the room - the rise in the prison population in the context of significant on-going budget cuts. There needed to be a corresponding commitment to controlling the demand for prison places and properly financing alternatives to custody, including funding for specialist services to support female offenders, and proper investment in the prison establishment. In light of the government's commitment to austerity and its ongoing public sector cuts, commentators in The Guardian and Independent argued that there was little possibility for the level of investment required to integrate meaningfully rehabilitation into prison life. Despite its wariness, The Guardian continued to publicise the prison reform agenda for the rest of the month, running campaigning articles on topics such as: the death in prison of a new mother taken off suicide watch; the need to reduce the number of women in prison; the problems of private prisons; and drug drones and demoralised prison staff. It also gave Michael Gove space to present his case for implementing a cost-free cultural revolution. 
More significantly, Cameron's ideological repositioning was also welcomed by conservative broadsheets. The Times and Daily Telegraph viewed it as part of a wider strategy to seize the Blairite centre ground vacated by Labour under Jeremy Corbyn. Michael Gove's plan to transform prison education was backed by the Times, with the caution that political bravery would be required to face down the 'bang 'em up' wing to the right of the Conservative party. The Daily Telegraph was also supportive, publishing an article by Danny Kruger, chair of the criminal justice charity Only Connect and Cameron's former speechwriter, arguing that prison as a sentencing option should be removed for all but the most serious offences. The Sunday Telegraph carried an article, co-authored by Michael Gove and Chris Grayling, headlined 'We're getting smart on crime, not going soft' extolling the virtues of the new Conservative policy position on prisons.

The common ground around the Cameron-Gove reform agenda represented a rare moment of alignment between liberal and conservative broadsheets that defend trenchantly opposed positions on most social policy issues. The fact the reforms were being proposed in the first prime ministerial speech on prisons for a generation ensured their widespread press coverage. It also attracted the attention of Britain's most senior political broadsheet journalists and commentators, which further elevated the visibility of the prison crisis as a policy priority. There was enthusiastic support for the raft of sure-fire reforms from penal campaigners. This remarkable transformation in the Conservative party's stance was the moment penologists and the penal reformers had been waiting for. The broadsheets were also 'on message'. Given the context of a dramatically falling crime rate, there appeared to be a genuine window of political opportunity for finally reversing penal populism and nullifying the inevitable tabloid backlash.

\section{The conservative tabloid reaction: a question of security}

The parts of the Cameron-Gove reform agenda that hinted at prison downsizing were anathema to the conservative tabloids, who moved quickly to set the terms of debate. They initially focused their firepower on the proposals that would enable former prisoners to apply for jobs without declaring their criminal record and the planned use of GPS tagging to facilitate weekend or evening imprisonment for low risk offenders in employment. The Sun's headline on 9 February 2016, 'Hide crimes and misdemeanours: PM says lags can lie on CVs', was reinforced with the warning that the government was 'taking a risk with liberal ideas like weekend sentences. They cannot include violent thugs.' The newspaper also took issue with Cameron's claim that jails should be for 'care, not just punishment'. As far as the Sun was concerned, 'They're not meant to be happy. Besides, we often see lags high on drugs, cheerfully posting on Facebook with smuggled phones. It must be possible to cut the signal and clean those prisons up'.

The Daily Mail's front page on 8 February 2016, 'Soft justice fears as Cameron plans to free offenders from Monday to Friday', was accompanied by a main article, 'Prisoners won't have to declare convictions on job applications under plans unveiled by David Cameron as he faces claims of soft justice over 'stupid' reforms'. The risks posed to the public by the 
'weekend jail' scheme for supposedly low risk offenders were also highlighted by the Daily Express:

"In falling for the propaganda of the anti-prison lobby Cameron is rejecting one of the Conservatives' most successful policies. It is more than 20 years since the then Home Secretary Michael Howard stood up at the Tory party conference and declared 'prison works'. He lengthened sentences, allowed juries to take into account a suspect's decision to keep silent during police questioning and undertook other reforms. The prison population began to rise almost immediately. AND so sharply did the crime rate fall that the unthinkable happened: Labour, too, adopted tougher crime policies so that by the end of the Blair years the prison population was nearly double what it was in 1993. And as it rose, crime fell. The anti-prison lobby has desperately tried to come up with an alternative explanation. The one explanation they will not accept is the obvious one: that when criminals are in jail they cannot commit crimes outside prison." 12

The conservative tabloids ratchetted up their attacks on Cameron's prison reforms with exposés of the latest 'soft justice' prison scandals. Stories included: the failure to jail the leader of an Asian paedophile gang because he was allowed to flee to Bangladesh, from where he was taunting the police; the inability to prevent convicted serial killer, Levi Bellfield, from tormenting the parents of Milly Dowler from the 'comfort' of his prison cell; unduly lenient sentences; and the axing of a disastrous $f 23$ million electronic offender tagging scheme. The 'soft justice' theme was buttressed with 'prison anarchy' stories of prisoners who were: taking other prisoners and officers hostage; recording songs on mobile phones and posting them on social media sites; holding pizza and beer 'block parties'; using drones to smuggle drugs and mobile phones into jail; and radicalising other prisoners into Islamist extremism. By the end of February, while the broadsheets continued to debate the practicalities of the Cameron-Gove prison reforms, the conservative tabloids were arguing that a draconian crackdown was needed to take control of the prison system. The image of 100 infants behind bars was soon replaced with an image of 131 jihadist terrorists for whom the government was proposing to build a new maximum security prison. Nicknamed the 'British Alcatraz', its purpose would be to tackle the threat of jihadist radicalisation within prisons. The government was belatedly being forced to acknowledge the conservative tabloids' stance that prison wings were being transformed into jihadi training camps.

\section{Breaking point: Brexit and the populist punitive surge}

Appearing before the Justice Select Committee in March 2016, Michael Gove confirmed that prison reform would be the heart of the Queen's speech. In May 2016 Gove wrote an enthusiastic preface to the Royal Society of Arts (RSA) 'The Future Prison' report, again promoting the reform agenda.13 The Justice Select Committee reinforced the case for reform, warning that the rising number of suicides and escalating violence in prisons required urgent action.14 Dame Sally Coates' report was also published, promoting the argument that raising the standard of educational provision was the key to turning 
offenders' lives around and reducing reoffending.15 However, by this time the looming Brexit referendum was dictating the news agenda. The broadsheets, whilst still supportive of the reforms, recognised that they could be derailed by the political fallout from a referendum campaign that was splitting the Conservative government and pitching Cameron, who wanted to remain in the EU, against Gove, who was a leading Brexiteer. The conservative tabloids seized the opportunity to politicise fully the 'soft justice' prison scandal narrative by working it into their virulent pro-leave campaign. A barrage of 'enemy within' stories, featuring Islamist terrorists, criminal migrants and foreign criminals who were allegedly playing the system and making a mockery of British justice, were used to evidence the erosion of territorial sovereignty and reinforce the case for taking back control of the country's borders. The 'twin evils' of freedom of movement-presented as offering a multitude of criminals unfettered access to the UK-and the European Court of Human Rights - constructed as making it impossible to deport them once caught and convictedprovided potent material for relentless anti-EU tabloid campaigning. At one and the same time, Michael Gove was championing prison reform whilst conceding that the sovereignty of the British criminal justice system was being undermined by membership of the European Union. Running in tandem with the surfacing of deep-seated social schisms, intraparty divisions, and the gap between expert views and popular sentiment, the conservative tabloid concentration on incendiary law and order issues was critical in shifting the balance of forces towards the leave campaign. This was despite the shocked reaction to the brutal murder of the Labour MP Jo Cox on 16 June by a far right extremist.

By the time the UK voted on 23 June 2016, the political consensus uniting David Cameron and Michael Gove had been destroyed in a storm of recriminations.16 The broadsheet consensus around the urgency of prison reform had been progressively unravelling for months as newspapers took opposing sides over Brexit, and prisons fell further and further down the news agenda. Cameron resigned as Prime Minister and Gove was sacked by Cameron's successor and former Home Secretary, Theresa May. By September, Elizabeth Truss, the new Justice Secretary, appearing before the Justice Select Committee, seemed to distance herself from the Cameron-Gove prison reform agenda. Repeating the increasingly hollow mantra that prisons would see their biggest overhaul in a generation, a Prison Safety and Reform White Paper was published in early November 2016. There was a clear shift in emphasis towards prison securitisation, with the promise to invest an austerity-busting additional $£ 104$ million on an extra 2,500 frontline prison officers to combat drug abuse and a rising tide of violence. The direction of investment, however, represented a U-turn away from Cameron and Gove's policy position. Rehabilitation could now only be considered after law and order had been restored throughout the anarchic prison system.

Days later, this shift in focus towards prison securitisation was reinforced when a mass riot in Bedford prison caused $£ 1$ million-worth of damage, a prisoner was murdered at Pentonville prison, prisoners escaped from two prisons, and the Ministry of Justice had to obtain a High Court injunction against industrial action being taken by prison officers after an estimated 10,000 walked out over unacceptable levels of violence and intimidation. Tabloid outrage at 'prison anarchy' peaked when a prisoner allegedly called a radio phone-in about prison reform from his cell, and inmates at HMP Guys Marsh in Dorset posted 
'cellfies' on Facebook that showed them partying with smuggled food, drugs, alcohol, video game consoles and wads of $£ 20$ notes. The instruction to government was clear: re-impose law and order in prisons. A Daily Mail editorial on 18 November 2016, entitled 'Even softer prisons are not an answer' demanded 'an immediate, and draconian, crackdown'. By the end of November, discussion of rehabilitative prison reform had all but disappeared from the news agenda. The government announced that it was considering longer sentences for violent offenders and the Lord Chief Justice advocated a toughening-up of non-custodial sentences. As the tabloids had predicted almost a year earlier, the Ministry of Justice confirmed that Cameron's plan for lower-risk criminals to spend only weekends in jail was unworkable and would be dropped. The year ended with further 'prison anarchy' news coverage of yet more rioting prisoners. Following what was described as the worst prison riot since Strangeways, 240 prisoners were moved out of HMP Birmingham. Hundreds of armed inmates rioted for twelve hours, setting fires, raiding the prison pharmacy, battling anti-riot squads and posting remarkable photos and videos on social media, publicising their exploits. The Birmingham prison riot was followed by inmates releasing videos of themselves starting fires and taking control of a wing of HMP Swaleside in Kent. In addition to restoring order, the priority task for the authorities was in attempting to block the flow of politically explosive 'the lags have taken over' footage being disseminated by news agencies. The virtual collapse of control and discipline across parts of the prison estate was evident for all to see and hear. In a damning assessment of government policy, Phil Wheatley, the former chief executive of the National Offender Management Service and director general of the prison service, repeated that the prison service was being wrecked by ill thought-out operationally disastrous policies that had led to:

" the loss of experienced prison managers and staff, too few prison officers of any sort, wages that make it difficult to recruit and retain staff, and a reduction in privileges and access to treatment interventions and regime activities that have been corrosive for prisoners. The situation is now parlous and will only be resolved by a prolonged period of policy stability and investment. It will take years to put right." 17

The legislative changes contained in the Prison Safety and Reform White Paper formed the basis for the Prisons and Courts Bill 2016-17. A second reading of the Bill, which had broad parliamentary support, took placed in March 2017, but was lost after Theresa May called a snap general election. To the consternation of campaigning groups, prison reform was dropped from a Brexit-dominated Queen's speech. The view among prison reformers, who had been so enthused by the Cameron-Gove initiative, was summed up by Chief Inspector of Prisons, Peter Clarke:

"I am very disappointed that prison reform has not found a place in the Queen's speech. The Prisons and Courts Reform Bill, introduced last year, enjoyed broad parliamentary support and had made real progress through Parliament until it was lost when the general election was called. This is a missed opportunity to forge ahead with prison reform. The law would have required the government to respond to our findings. We will continue to report the harsh reality of what we find in our prisons - all too many of which are dangerous for prisoners and staff alike and are 
failing in their duty to rehabilitate and reform prisoners. We will continue to press

for strong leadership and a real commitment to reform." 18

During 2017, in the context of ongoing disturbances, the reform wheel turned full circle with securitisation dominating the prison agenda. The government committed more resources to recruit more prison officers and create new prison places. A further $£ 3$ million was set aside for 5,600 body-worn cameras, the introduction of new handcuffs and restraints for prison staff and the trial use of incapacitant spray to control violent offenders. Priority prisons were given an additional $£ 10$ million to pay for surveillance cameras, metal detectors, mobile phone detectors and dog patrols.

\section{Conclusion}

In this article we have examined the role that British conservative tabloid newspapers play in promoting penal populism and neutralising liberal prison reform initiatives. Our argument is not that the tabloids single-handedly undermined the Cameron-Gove prison reform agenda-any more than we would argue that they single-handedly secured the leave vote to take the UK out of the European Union. There are numerous competing dynamics around both issues. However, we would argue that the power of conservative tabloid adversarialism resides in its reflexive ability to generate a striking array of populist positions. In so doing these newspapers are able to find interacting breaking points that can tip the balance of public sentiment and political resolve one way rather than the other. And it is because of this aptitude that toxic policy issues like prison reform will continue to run the risk of being dashed on the rocks of conservative tabloid adversarialism.

Reforms championing tighter controls over custodial sentencing and reducing prison numbers will always face an uphill struggle. The post-war history of such initiatives instructs that, in terms of political receptiveness, it is rarely the right time. Opposing national newspaper interpretations of the 'real' scandal of British prisons, underpinned by contradictory moral positions and penal philosophies, also act as a major block on liberal prison reform in England and Wales. In the weeks and months following David Cameron's potentially tenure-defining speech, the conservative tabloid backlash was directed with remarkable effectiveness to undermining the case for alternatives to imprisonment and prioritising rehabilitation. The immediately resonant image of prison anarchy, exacerbated by a succession of 'soft justice' stories, gave the powerful message that reform was a luxury on which Cameron's government could ill afford to waste time. The conservative tabloids also widened their attack by publishing a plethora of stories that highlighted the risks posed by Islamist terrorists, criminal migrants and foreign criminals. At key moments, the conservative tabloids also found unexpected allies in the inmates who were using social media to demonstrate who really controlled the prisons. The sheer volume of 'cellfies' circulating on newspaper websites and social media told their own carnivalesque story: the lunatics had taken over the asylum. Any reforms that might advantage prisoners could only be considered after those prisoners, and Britain's anarchic prisons more generally, had been 
brought back under control. And the only way to achieve the necessary end to an ongoing scandal of 'soft justice' was through greater securitisation and retribution.

As the European Union referendum approached, conservative tabloid exploitation of stories exemplifying prison anarchy and ineffective border controls, broke the Cameron-Gove reform agenda apart. The stark lesson to be learned is that the scandal-ridden prison is a particularly toxic issue marked by serial policy failure. Consequently, in a febrile, intermediatised penal populist context, why would any political leader take on the manifest risks associated with embarking on liberal prison reform?

\section{Notes}

1. M. Fitzgerald and J. Sim, British Prisons, Oxford, Blackwell, 1975; A. E. Bottoms, 'The philosophy and politics of punishment and sentencing', in C. Clarkson and R. Morgan, eds., The Politics of Sentencing Reform, Oxford, Clarendon Press, 1995.

2. D. Garland, The Culture of Control: Crime and Social Order in Contemporary Society, Oxford, Oxford University Press, 2001; J. Pratt, Penal Populism, London, Routledge, 2007; J. Roberts, L. Stalans, D. Indermaur and M. Hough, Penal Populism and Public Opinion: Lessons from Five Countries, New York, Oxford University Press, 2003.

3. The Howard League, Penal Reform Groups: New Media and the Mainstream News, London, Howard League for Penal Reform, 2015.

4. See also M. Ryan, Penal Policy and Political Culture, London, Waterside Press, 2003; P. Mason, 'Lies, distortion and what doesn't work: monitoring prison stories in the British media', Crime, Media Culture, vol. 3, no. 2, pp. 251-67; G. Birkett, 'Penal reform discourse for women offenders:

campaigners, policy strategies and "issue reframing"', Crime, Media, Culture, vol. 10, no. 2, 2014, pp. 115-132.

5. S. Barnett, 'The age of contempt', The Guardian, 28 October, 2002.

6. J. Tunstall, Newspaper Power: The New National Press in Britain, Oxford, Oxford University Press, 1995; M. Bromley, 'The "tabloiding" of Britain: "quality" newspapers in the 1990s', in M. Bromley and H. Stephenson, eds., Sex, Lies and Democracy: The Press and the Public, Harrow, Addison Wesley Longman, 1998; P. J. Boczkowski, Digitizing the News: Innovation in Online Newspapers, Cambridge, Mass., MIT Press, 2004; M. T. Bastos, 'Digital journalism and tabloid journalism', in B. Franklin and S. Eldridge II, eds., Routledge Companion to Digital Journalism, London, Routledge, 2017.

7. C. Greer and E. McLaughlin 'News power, crime and media justice' in A. Leibling, S. Maruna and L. McAra, eds., The Oxford Handbook of Criminology, 6th edition, Oxford, Oxford University Press, 2017; C. Greer and E. McLaughlin, 'Theorizing Institutional Scandal and the Regulatory State', Theoretical Criminology, vol. 21, no. 2, 2017, pp. 112-132.

8. P. Mason, 'Lies, distortion and what doesn't work: monitoring prison stories in the British media', Crime, Media Culture, vol. 3, no. 2, 2006, pp. 251-67; I. O'Donnell and Y. Jewkes, 'Going home for Christmas: prisoners, a taste of freedom and the press', The Howard Journal, vol. 50, no.1, 2011, pp. 75-91; J. Silverman, Crime, Policy and the Media: the Shaping of Criminal Justice, London, Routledge, 2010; M. Dean, Democracy Under Attack: How the Media Distort Policy and Politics, Bristol, Policy Press, 2011. 
9. D. Cameron, Prison Reform, speech to Policy Exchange, 8 February 2016.

10. The Times, 8 October 2015; see also Ministry of Justice, speech by Michael Gove, 'The treasure in the heart of man-making prisons work', speech to Prisoners' Learning Alliance, 17 July 2015.

11. Written ministerial statement made by the Lord Chancellor and Secretary of State for Justice, Michael Gove, 25 November 2015.

12. R. Clarke, 'David Cameron must NOT forget that prison works', Daily Express, comment, 9 February 2016.

13. Royal Society of Arts, The Future Prison, London, RSA, 2016.

14. House of Commons Justice Committee, Prison Safety, Sixth Report of Session 2015-16, HC625, London, TSO, 2016.

15. Dame S. Coates, Unlocking Potential: A Review of Education in Prison, London, Ministry of Justice, May 2016.

16. C. Oliver, Unleashing Demons, London, Hodder and Stoughton, 2017; T. Shipman, All Out War: The Full Story of Brexit, London, Harper Collins, 2017.

17. P. Wheatley, 'It took years of Tory cuts and wild policy swings to create this prisons crisis', The Guardian, 12 December 2106.

18. HM Chief Inspector of Prisons' response to Queen's Speech, 21 June 2017. 